\title{
Perubahan Ekosistem Hutan Pinus Puncak Becici Dlingo Akibat Kegiatan Pariwisata
}

\author{
Ayu Utamia ${ }^{a}$, Henri Krismawan ${ }^{b}$, Muhammad Nurcholis ${ }^{c}$ \\ a Teknik Lingkungan, Universitas Pembangunan Nasional Veteran Yogyakarta, Jl. SWK 104 Ring Road, \\ Yogyakarta, 55283 Indonesia \\ b SDS Institute, Prancak, Dukuh, Kec. Sewon, Bantul, Daerah Istimewa Yogyakarta 55188, Indonesia \\ ${ }^{c}$ Ilmu Tanah, Universitas Pembangunan Nasional Veteran Yogyakarta, Jl. SWK 104 Ring Road, Yogyakarta, \\ 55283 Indonesia \\ ${ }^{a}$ Corresponding author: ayu.utami@upnyk.ac.id \\ b)henri.krismawan@gmail.com \\ ${ }^{c}$ nurcholis@upnyk.ac.id
}

\begin{abstract}
Tourism development is one of the ways to increase the region income. The impact from the development has both positive and negative sides including for environmental and ecosystem. Dlingo District has a lot of tourism petensial, Becici Pine Forest is one of it which is included as a Protection Area. The objective of this research is to identify ecosystem changes in Becici Pine Forest due to the development of tourism. The method used in this research is a quantitative method with mix method. Several methods such as observation, field survey, satellite imagery, and interviews were used for data collection. For data analysis, this research used geographic information systems, descriptive analysis, and mathematical calculations as methods. From the descriptive analysis of observation and survey data, it was found that the tourism development of the Puncak Becici Pine Forest, Dlingo led to changes. The Pine Forest area clearing has increase which shows from the increasing of tourism facility building in the area and the reducing of forest area. The environment and ecosystem impact can be seen from the land use change of the forest area. The result of this study can be used as the guideline to regulate the tourism development at Becici Pine Forest based on ecosystem and environmental management.
\end{abstract}

Keywords: Becici Pine Forest; Dlingo; Ecosystem; Environmental Management; Tourism area

\begin{abstract}
ABSTRAK
Mengembangkan pariwisata merupakan salah satu upaya dalam menambah pendapatan suatu daerah. Perkembangan pariwisata tidak hanya menimbulkan dampak yang dapat membangun suatu daerah tersebut, tetapi juga memiliki dampak terhadap ekosistem. Kecamatan Dlingo memiliki banyak potensi pariwisata, salah satunya adalah Hutan Pinus Becici yang masuk ke dalam Kawasan lindung. Tujuan dari penelitian ini adalah mengidentifikasi beberapa perubahan ekosistem yang terjadi di hutan pinus becici akibat adanya perkembangan kegiatan pariwisata. Metode yang digunakan dalam penelitian ini merupakan metode kuantitatif dengan metode campuran (mix method). Untuk pengumpulan data, digunakan beberapa metode, antara lain observasi, survey lapangan, citra satelit, dan wawancara. Metode yang digunakan dalam analisis data antara lain dengan menggunakan sistem informasi geografi, analisis deskriptif, dan perhitungan matematis. Berdasarkan analisis deskriptif yang dilakukan dari hasil observasi dan survey, didapatkan bahwa perkembangan wisata Hutan Pinus Puncak Becici, Dlingo menyebabkan terjadinya perubahan. Luasan dari hutan pinus yang dibuka lahannya untuk kawasan wisata bertambah. Hal ini menunjukkan bahwa terjadi perubahan pada ekosistem hutan pinus di wilayah tersebut. Hasil penelitian ini diharapkan dapat digunakan untuk menyusun suatu arahan pedoman mengenai perubahan ekosistem hutan pinus Becici sebagai dokumen acuan pengembangan pariwisata dengan konsep ramah lingkungan.
\end{abstract}

Kata kunci: Dlingo, Ekosistem, Hutan Pinus Becici, Kawasan Hutan, Pengelolaan Lingkungan

\section{PENDAHULUAN}

Perkembangan pariwisata merupakan salah satu upaya dalam menambah pendapatan suatu daerah yang dapat memberikan dampak positif dan negatif. Dampak positif yang dapat dirasakan salah satunya adalah dari aspek ekonomi yaitu meningkatkan pendapatan, membuka lapangan pekerjaan, meningkatnya kesejahteraan masyarakat sekitar, menaikan penghasilan dari pajak pariwisata, dan juga dapat berperan sebagai multiplier effect atau dapat menggandakan kegiatan-kegiatan lain (Butler \& Pearce, 2003). Selain itu, dampak lain yang dapat terjadi akan mempengaruhi komponen-komponen ekosistem seperti air, udara,

\footnotetext{
$1_{*}$ Ayu Utami:ayu.utami@unyk.ac.id
} 
tanah, vegetasi, kehidupan liar, dan lain-lain. Untuk wisata alam, perkembangan pariwisata akan menyebabkan berkurangnya manfaat dan fungsi dari hutan tersebut, seperti konservasi keanekaragaman hayati dan konservasi komponen abiotik. Dampak lain yang juga tidak bisa dihindari adalah beban bagi lingkungan, antara lain tanah longsor, erosi, berkurangnya vegetasi, pembabatan pohon, koleksi vegetasi endemik yang berkurang, migrasi fauna, kuantitas dan kualitas air menurun, dan emisi udara (Ismayanti, 2010).

Kecamatan Dlingo adalah salah satu bagian dari kecamatan di Kabupaten Bantul, Provinsi Daerah Istimewa Yogyakarta. Secara geografis Dlingo terletak di Kabupaten Bantul paling timur, berbatasan dengan Kabupaten Gunungkidul dan wilayahnya berbukit-bukit (Bantul, 2019). Kecamatan Dlingo memiliki kawasan wisata dengan lokasi yang berjejer dan berjarak tidak jauh antara satu kawan dengan yang lain. Objek yang ditawarkan juga sangat banyak dan beragam (Jogja, 2019). Berdasarkan keterangan warga, kawasan wisata di Kecamatan Dlingo dibagi menjadi 3 jenis lahan yang dimantaatkan untuk wilayah pengembangan yaitu lahan kas desa, lahan pemerintah, dan lahan pribadi. Dari jenis lahan pengembangan tersebut, terdapat 8 kawasan yang merupakan lahan pemerintah, 8 kawasan lahan pribadi, dan 3 kawasan pariwisata menggunakan lahan desa.

Kecamatan Dlingo memiliki banyak potensi pariwisata, salah satunya adalah Hutan Pinus Becici. Hutan Pinus Becici berada di Desa Muntuk, Kecamatan Dlingo yang terletak tidak jauh dari Hutan Pinus Mangunan. Hutan pinus seluas 4,4 hektar dengan hawa yang sejuk dan pemandangan yang indah, dan pada tahun 2017 menjadi salah satu objek yang dikunjungi mantan Presiden Amerika Serikat Barack Husein Obama saat di Indonesia (Zuraya, 2017).

Objek wisata yang dibuka pada awal 2015 memiliki fungsi ganda pada saat itu, yaitu rata-rata pohon pinus di sekitar hutan ini diambil getahnya guna dijadikan terpentin yang langsung dikelola oleh Dinas Kehutanan dan Perkebunan Provinsi Daerah Istimewa Yogyakarta dan semenjak ramai dikunjungi oleh pengunjung kegiatan menyadap getah di pohon pinus dihentikan untuk lebih difokuskan sebagai objek wisata yang dikelola oleh Pokdarwis (Kelompok Sadar Wisata) setempat. Disini terdapat berbagai macam fasilitas seperti gardu pandang, spot foto, hammock atau ayunan, camping ground, toilet dan lokasi parkir kendaraan.

Hutan Pinus Becici merupakan hutan yang masuk dalam kawasan lindung. Dalam pengelolaan kawasan lindung, perlu diperhatikan beberapa aspek dalam pengelolaannya agar ekosistem kawasan lindung tetap terjaga (Republik Indonesia, 1990). Dalam penentuan arahan kawasan hutan lindung, perlu diperhatikan ekosistem baik biotik maupun abiotik yang terdapat pada suatu kawasan. Potensi yang dimiliki oleh kawasan hutan lindung tersebut yang digunakan sebagai pertimbangan dalam pengelolaan (Sinery \& Mahmud, 2014).

Perkembangan pariwisata di wilayah ini terlihat cukup pesat dari tahun 2015. Hal ini menimbulkan keresahan penurunan kualitas lingkungan dengan adanya perubahan ekosistem yang terjadi. Untuk itu, penelitian ini dilakukan dengan tujuan untuk mengidentifikasi perubahan-perubahan yang terjadi pada ekosistem hutan pinus becici akibat adanya kegiatan pariwisata yang berkembang di daerah tersebut. Penelitian ini diharapkan dapat digunakan untuk menyusun suatu arahan pedoman mengenai perubahan ekosistem hutan pinus becici sebagai dokumen acuan pengembangan pariwisata dengan konsep ramah lingkungan.

\section{METODE}

Penelitian ini menggunakan metode campuran atau "Mixed-Method". Metode ini menggunakan pengumpulan dan analisis data baik kuantitatif maupun kualitatif dengan satu atau beberapa pendekatan yang diintegrasikan pada satu atau beberapa tahapan penelitian (Dörnyei, 2007). Metode yang dilakukan diataranya antara lain pengumpulan data (primer dan sekunder) dan analisis data.

\subsection{Teknik Pengumpulan Data}

Tahap awal dalam pengumpulan data primer adalah dengan observasi dan survey lapangan. Observasi dan survey dilakukan dengan melakukan pengamatan secara menyeluruh mengenai kegiatan yang ada di kawasan wisata Hutan Pinus Puncak Becici. Selain itu diamati pula faktor-faktor yang 
cenderung mempengaruhi perkembangan pariwisata yang menyebabkan perubahan. Metode yang dilakukan pada tahap pengumpulan data primer lainnya adalah dengan wawancara. Wawancara dilakukan untuk mendapatkan informasi dari pihak tertentu agar mendapatkan data yang diperlukan dalam penelitian. wawancara dilakukan secara langsung kepada stakeholder dan masyarakat pelaku wisata. Selain itu juga dilakukan diskusi dengan stakeholder terkait untuk memberikan masukan dan mendapatkan data yang terkait dengan penelitian.

Dalam pengumpulan data sekunder, data yang diambil bersumber dari referensi lain yang dapat mendukung analisis dalam penelitian. Data yang diambil dari berbagai instansi berupa data-data stastistik dan informasi lain yang relevan dan terkait dengan kegiatan ini. Sumber utama adalah data yang berasal dari pelaku-pelaku kegiatan wisata dikawasan puncak becici dan sumber-sumber lain yang bisa dipertanggung jawabkan. Dalam pekerjaan ini data sekunder yang dikumpulkan dari tahun 20152019 yang berupa:

1. Kondisi wilayah.

2. Dokumen penataan ruang kawasan.

3. Peta Wilayah.

4. Dokumen hasil kajian yang relevan.

5. Studi Pustaka/Peraturan Perundangan.

\subsection{Pengolahan dan Analisis Data}

\subsubsection{Sistem Informasi Geografi (SIG)}

Perubahan tutupan lahan dari suatu wilayah dapat dilakukan untuk mendeteksi perubahan lingkungan pada suatu wilayah. Data perubahan tutupan lahan secara periodik dapat mengidentifikasi seberapa luas berkurangnya suatu lahan atau bertambahnya suatu lahan. Data tutupan lahan secara periodik bisa dilihat dalam data satelit. Data satelit dapat mengklasifikasikan jenis tutupan lahan yang ada pada suatu wilayah. Perubahan jenis tutupan lahan dapat dilihat dari luasan yang dibandingkan dari data tersebut secara periodik. Data satelit yang digunakan pada penelitian ini adalah data Landsat yang didapatkan dari tools google earth pada tahun 2015-2019.

Perubahan tata guna lahan juga merupakan cara mengidentifikasi perubahan yang terjadi di suatu lingkungan. Data luasan tata guna lahan bisa didapatkan dari peta penggunaan lahan. Perubahan luasan pada penggunaan lahan dapat mendukung data perubahan luasan tutupan lahan. Pada penggunaan lahan, akan terlihat perubahan tutupan lahan akan digunakan akan berubah menjadi jenis lahan tertentu. Perhitungan pertambahan luasan bukaan lahan pada hutan pinus becici didapatkan dengan perhitungan perubahan luasan lahan hijau yang dapat diamati pada di satelit kemudian dihitung luasan tersebut menggunakan poligon pada tools google earth.

\subsubsection{Potensi Dampak Lingkungan}

Pada setiap kegiatan manusia yang merubah kondisi suatu lingkungan, dapat dilihat potensi dampak yang akan terjadi. Pencemaran, emisi yang dihasilkan, dan dampak sosial ekonomi bisa diperkirakan dengan adanya berbagai kegiatan pengembangan suatu wilayah. Salah satu kegiatan yang berpotensi menimbulkan dampak lingkungan adalah perubahan tutupan lahan dan penggunaan lahan. Untuk mendapatkan hasil potensi ini, analisis deskriptif dari data primer dan sekunder digunakan.

Potensi dampak lingkungan dianalisis berdasarkan faktor-faktor abiotik dan biotik yang mengalami perubahan. Perubahan-perubahan dapat dilihat pada saat survey lapangan dan observasi. Sedangkan analisis histori Kawasan wisata bisa didapatkan dari hasil diskusi dan wawancara. Menghubungkan antara kondisi eksisting dan histori dapat di analisis secara deskriptif berupa perubahan penggunaan lahan yang terjadi. 


\section{HASIL DAN PEMBAHASAN}

\subsection{Pengembangan Fisik Fasilitas Kawasan Wisata}

Secara umum arah pengembangan kawasan di Puncak Becici sudah ada dalam bentuk peta kawasan wisata Puncak Becici yang terpampang di pintu masuk kawasan. Dengan adanya peta kawasan wisata Puncak Becici ini menunjukkan bahwa konsep penataan kawasan sudah terkonsep, secara umum kedepan pengembangan dapat lebih terarah, sehingga proses perubahan ke arah yang lebih baik yang di dalamnya meliputi upaya-upaya perencanaan, implementasi dan pengendalian, dalam rangka penciptaan nilai tambah sesuai yang dikehendaki.

Selain itu, aturan yang sudah dibuat di kawasan Puncak Becici untuk mengatur dan membatasi kegiatan wisata di kawasan Puncak Becici masih terbatas pada aturan normative saja, belum mengarah pada aturan terkait dengan kawasan Lindung sebagai suatu kawasan yang spesifik, seperti aturan dilarang merokok, dilarang menginjak tanah selain di jalan setapak, dilarang merusak tanaman, dan lain sebagainya. Dalam pemenuhan fasilitas di kawasan puncak Becici, saat ini sudah dibangun beberapa sarana umum yang bisa dimanfaatkan oleh pengunjung dalam menikmati keindahan alam di puncak Becici. Berikut adalah sarana yang disedikan pengelola wisata di kawasan Hutan Pinus Puncak Becici. 1. Jaringan Air bersih

Sumber air yang ada di sekitar kawasan wisata Puncak Becici adalah berupa air bawah permukaan atau air sumur dan juga air permukaan yang berupa sungai. Pengembangan kawasan wisata puncak becici yang berkelanjutan perlu melihat kondisi sumber air yang digunakan untuk keperluan operasional kawasan tersebut. Berikut dipaparkan beberapa sumber air yang berpotensi dapat mendukung keberlanjutan kawasan wisata puncak becici.

Air yang digunakan di kawasan tersebut ditampung dalam drum-drum penampungan, dengan total volume penampungan adalah sekitar $>1000 \mathrm{~L}$. Air digunakan sebagai pendukung sanitasi dan kebutuhan domestik di kawasan tersebut. Penampung air dapat dilihat di beberapa lokasi di kawasan ini.

Jaringan air bersih di kawasan Puncak Becici diperolah dengan pembuatan sumur bor yang dibuat disekitar lokasi kawasan Puncak Becici, akan tetapi pada musim kemarau ketersediaan air diperoleh mengambil dari bawah dengan menggunakan tanki air minum yang bersumber dari PDAM. Ketersedian air bersih ditampung dalam bak penampungan yang berada disisi atas dari kawasan tersebut, berupa bak penampungan air yang terbuat dari fiber.

Bak penampungan air bersih berada di bagian atas dari kawasan Puncak Becici, bak tersebut menyediakan air bersih untuk kegiatan pengunjung, pengelola, warung-warung dan kegiatan lain yang memerlukan air bersih. Ada dua jenis air yang digunakan untuk pemenuhan kebutuhan wisata di kawasan puncak becici, yaitu air bawah permukaan dan air permukaan.

Air bawah permukaan merupakan sumber potensial dan paling mudah diakses sebagai sumber air di kawasan wisata puncak becici. Kuantitas sumber daya air dan juga kualitasnya merupakan komponen penting yang dibutuhkan dari sutu kawasan wisata. Air merupakan kebutuhan utama dari pengelolaan wisata. Air yang ditampung di penampung pada gambar 4.3., berasal dari air bawah permukaan. Kuantitas air harus tetap diperhatikan agar kebutuhan tetap terpenuhi. Agar kawasan wisata menjalankan fungsi berkelanjutan, konservasi air di wilayah tersebut bisa dilakukan. Konservasi dapat berupa membuat sumur resapan atau biopori.

Sedangkan air permukaan adalah air yang berasal dari air hujan yang jatuh ke permukaan tanah, sebagian menguap dan sebagian lainnya mengalir ke sungai, saluran air lalu disimpan di dalam danau, waduk dan rawa. Air permukaan tidak terdapat di sekitar kawasan wisata puncak becici. Oleh karena itu, sumber air wilayah tersebut perlu diperhatikan kuantitasnya, jika kuantitas tidak bisa dijaga, konservasi perlu dilakukan di kawasan wisata tersebut. 


\section{Sanitasi dan Penyaluran Limbah}

Pemanfaatan air di kawasan puncak becici yang dimanfaatkan untuk kegiatan warung-warung, MCK dan kegiatan cuci mencuci, dalam pemanfaatan limbah atau pengelolaan limbah masih belum maksimal. Hal tersebut dapat terlihat dengan adanya buangan air yang dibiarkan mengalir begitu saja dikawasan wisata puncak becici, sehingga kedepan perlu adanya pengelolaan limbah tersebut.

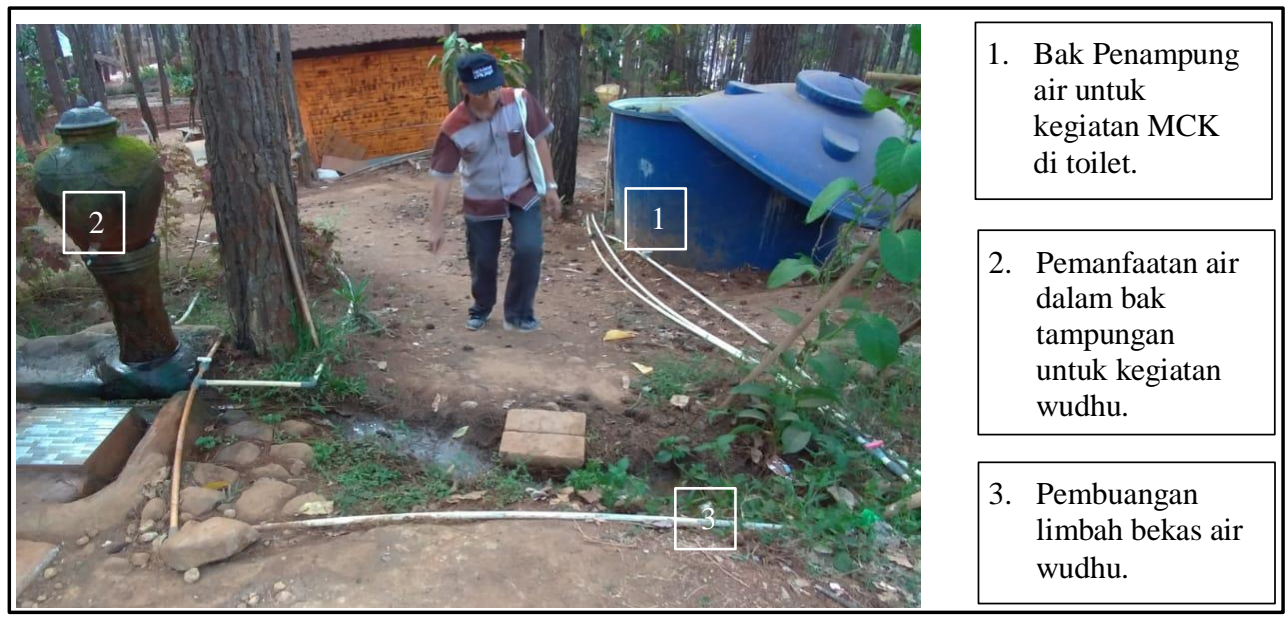

Gambar 1. Pemanfaatan Air dan Kondisi Air Limbah Bekas Wudhu (Sumber: Penulis)

Kondisi sanitasi dan penyaluran air limbah di kawasan Puncak Becici dari hasil survei secara umum sudah dikelola walau masih sederhana dan belum memenuhi standar ideal. Terlihat beberapa bangunan sanitasi dan penyaluran limbah sudah dibuat dan dimanfaatkan sebagai sarana pendukung kegiatan wisata. Hal tersebut dapat dilihat pada Gambar 1.

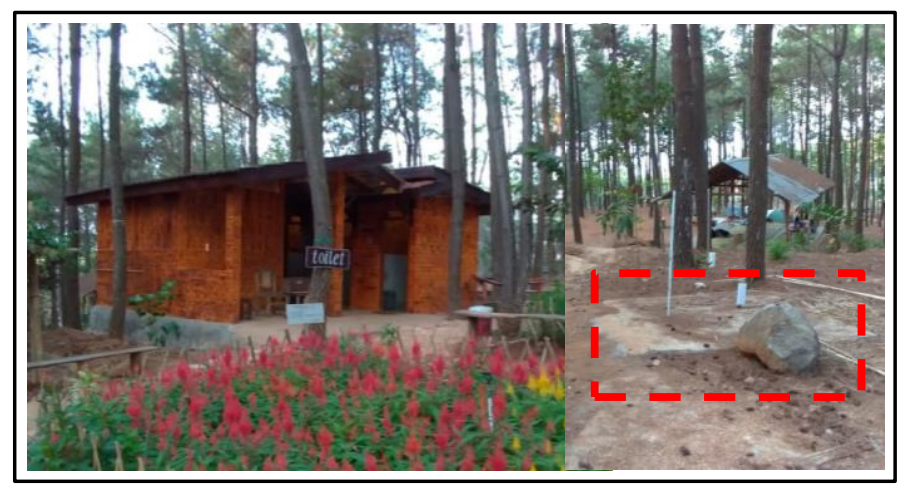

Gambar 2. Kondisi Toilet dan Saptictank di Dalam Kawasan Puncak Becici (Sumber: Penulis)

Kondisi toilet di kawasan tersebut cukup baik. Pada Gambar 2 terlihat bahwa kondisi tersebut dapat diketahui dengan terlihat dari pengelolaan lingkungannya termasuk kondisi toilet dari kawasan wisata. Kebutuhan sanitasi berhubungan erat dengan kondisi perairan yang ada di wilayah tersebut. Jika kebutuhan air tercukupi, maka kondisi sanitasi di kawasan tersebut akan tetap baik. Kebersihan merupakan hal paling mendasar dari estetika. Kawasan wisata harus sangat memperhatikan estetika tempat wisatanya. Jika kebutuhan sanitasi tidak terpenuhi, estetika kawasan wisata akan terganggu dan akan menurunkan daya tarik kawasan tersebut ke pada wisatawan.

Kondisi toilet yang dibangun secara permanen dengan kebersihan yang cukup terjaga, limbah dari toilet tersebut dialirkan di samping toilet dengan bangunan septickteng yang sederhana. Sehingga secara umum sistem sanitasi yang diterapkan oleh pengelola kawasan Puncak Becici sudah menerapkan konsep 
pelestarian lingkungan, akan tetapi perlu adanya pengelolaan yang lebih baik sehingga kedepan tidak menimbulkan pencemaran yang lebih besar. Seperti contoh dengan menghitung banyaknya pertambahan kunjungan wisatawan ke lokasi kawasan, sehingga perlu mempertimbangkan kemampuan daya dukung dan daya tampungnya.

Selain limbah MCK, dikawasan Puncak Becici juga terdapat pembuangan limbah cucian dan dapur yang dibuang melalui pipa-pipa pembuangan ke bagian paling rendah dari kawasan tersebut. Pembuangan limbah tersebut dengan menggunakan system resapan yang berada di tepi kawasan bagian bawah. Pengelolaan limbah rumah cair tangga ke depan perlu dilakukan secara lebih baik, sehingga tidak akan ada lagi pencemaran dan kerusakan lingkungan yang diakibatkan oleh adanya limbah tersebut secara terus menerus.

\section{Sistem Persampahan}

Banyaknya pengunjung suatu kawasan wisata menuntut pengelola untuk mengelola lingkungannya dengan terpadu. Termasuk sampah yang dihasilkan, terlihat dari survey menandakan bahwa potensi sampah yang dihasilkan meningkat dengan adanya limbah sampah yang semakin meningkat pula.

Terlihat dari gambar hasil survey, tempat sampah di kawasan wisata becici kurang memadai. Volume sampah padat yang dihasilkan suatu daerah wisata akan cukup besar dengan bertambahnya pedagang di sekitar kawasan juga. Volume yang meningkat perlu dilakukan pengelolaan sampah yang terpadu agar kawasan tersebut tetap lestari dan fungsinya dapat terjaga.

Jika volume sampah pengunjung tidak dapat tertampung dengan baik, estetika dari kawasan wisata akan menjadi berkurang. Pengelolaan lingkungan yang baik akan menambah estetika dan daya tarik pengunjung. Pengelolaan sampah padat yang baik dapat mengurangi volume sampah yang akan dibuang. Selain itu, jika dilakukan pemanfaatan terhadap sampah padat yang ada, kawasan wisata Puncak Becici dapat dijadikan kawasan wisata percontohan yang lebih berwawasan lingkungan. Sampah padat dapat di pilah menjadi 3 jenis, layak buang, layak daur ulang, dan layak kompos. Jika sampah padat bisa dipilah dengan baik, hasil sampah dapat dimanfaatkan sebaik-baiknya oleh pengelola dari segi ekonomi. Selain itu, pemilahan yang baik dapat mendukung kondisi lingkungan yang lebih baik juga.

Sistem persampahan dikawasan Puncak Becici dari hasil survei hanya ada beberapa tempat sampah disudut-sudut kawasan, dengan berbagi bentuk dan jenis tempat sampah tersebut. Kondisi tempat sampah diloaksi tersebut sebagian besar pemanfaatannya kurang optimal, hal tersebut disebabkan karena kondisi tempat sampah yang kurang layak dan karena perilaku wisatawan yang kurang respon terhadap kebersihan lingkungan.

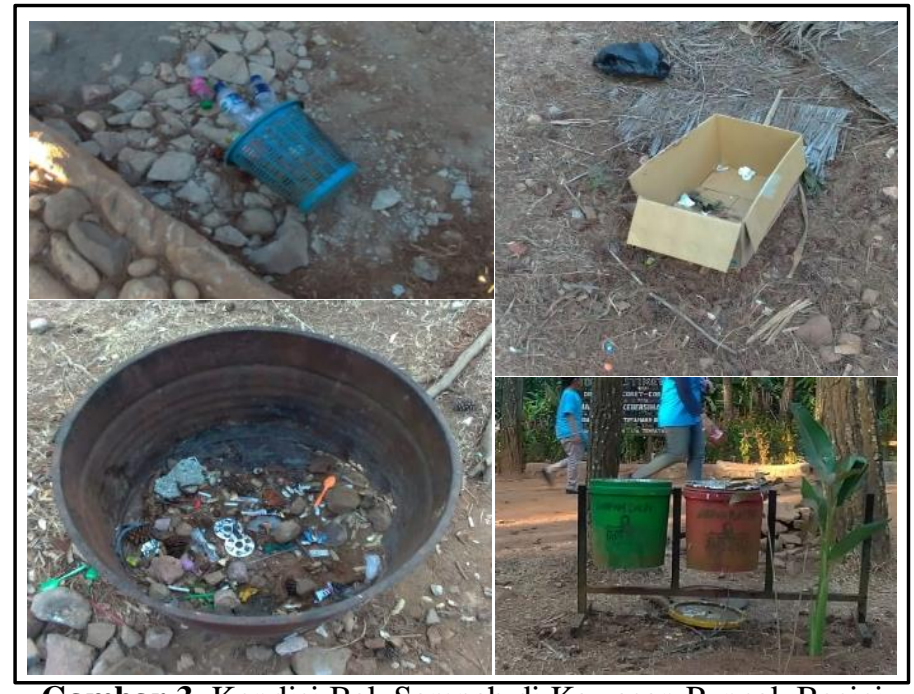

Gambar 3. Kondisi Bak Sampah di Kawasan Puncak Becici

(Sumber: Penulis) 
Tempat pembuangan sampah dari berbagai jenis bahan dan kondisi sudah tidak ideal lagi untuk dijadikan tempat sampah, sehingga peru adanya penyeragaman dari bentuk tempat sampah tersebut. Selain itu kebiasaan wisatawan yang datang berkumjung ke kawasan Puncak Becici juga cenderung kurang peduli terhadap kebersihan lingkungan, seperti contoh masih adanya sampah yang berserakan di sekitar kawasan tersebut, bahkan terdapat punting rokok di kawasan Puncak Becici. Seharusnya terdapat larangan untuk dilarang merokok di kawasan Puncak Becici tersebut, karena dapat menyebabkan terjadinya kebakaran hutan, larangan tersebut juga berlaku selain untuk wisatawan yang datang juga berlaku untuk pengelola kawasan Puncak Becici.

4. Jaringan Jalan/Pedestrian

Jalan setapak atau pedestrian yang ada di kawasan Puncak Becici dibuat berdasarkan pada perencanaan di peta kawasan, yang difungsikan sebagai akses pejalan kaki yang menghubungkan antara kawasan satu dengan kawasan yang lain. Jalan setapak ini dengan lebar antara 1 meter sampai dengan 1,5 meter yang terbuat dari batu hitam dan di kuatkan pada sisi kanan kiri dengan bangunan yang terbuat dari semen.

Pedestrian yang berada di dalam kawasan yang membelah ditengah-tengah tanaman pinus, pedestrian atau jalan setapak ini menghubungkan ke spot selfie satu dengan spot yang lain, sehingga pengunjung diharapkan melewati jalan setapak ini, selain itu jalan setapak yang sudah ada yang membelah di tengah pohon pinus masih satu jalur, sehingga belum mampu menampung untuk melewati jalan setapak tersebut.

Selain jalan setapak yang membelah diantara tanaman pinus yang masih satu jalur tersebut, juga terdapat jalan setapak yang merupakan akses pintu masuk lokasi wisata dengan sudah menerapkan dua jalur sebagai jalur masuk dan keluar. Selain itu kiri kanan jalur tersebut sudah ditanami dengan tanaman bunga yang warna-warni, sehingga mampu menciptakan nuasa yang berbeda dan lebih asri.

5. Kios dan Warung

Berjajar kios dan warung yang menjual berbagai macam makanan, minuman, souvenir dan barang-barang kebutuhan pengunjung saat ini berada di dalam kawasan Pucak Becici dengan dikelola secara terkoordinir. Adanya warung dan kios ini secara ekonomi mampu meningkatkan pendapat masyarakat, namun dari sisi teknis perlu dilakukan penataan yang lebih tepat dari mulai penempatan lokasi, jenis bangunan, bahan bangunan bahkan sampai desain bangunan yang lebih baik. Sehingga apabila penempatan yang tepat akan mengurangi dari kerusakan lingkungan, termasuk juga terkait dengan pengelolaan sampah dan limbah di warung dan kios tersebut secara mandiri.

6. Amphititer (Panggung) dan Gazebo

Bangunan fasilitas pendukung lainnya yang dibangun di kawasan Puncak Becici panggung pertunujkan dan gazebo serta gardu pandang dan masih banyak lagi merupakan bagian dari yang tidak terpisahkan terhadap dampak pengembangan kawasan tersebut.

Kondisi amphititer atau panggung untuk pementasan yang dibuat di tepian tebing yang cukup curam, kondisi tersebut dibuat untuk mendapatkan nuansa pemendangan pada bagian bawah. Pembuatan panggung selama ini dimanfaatkan selain untuk spot foto selfie juga tempat untuk kegiatan pementasan. 


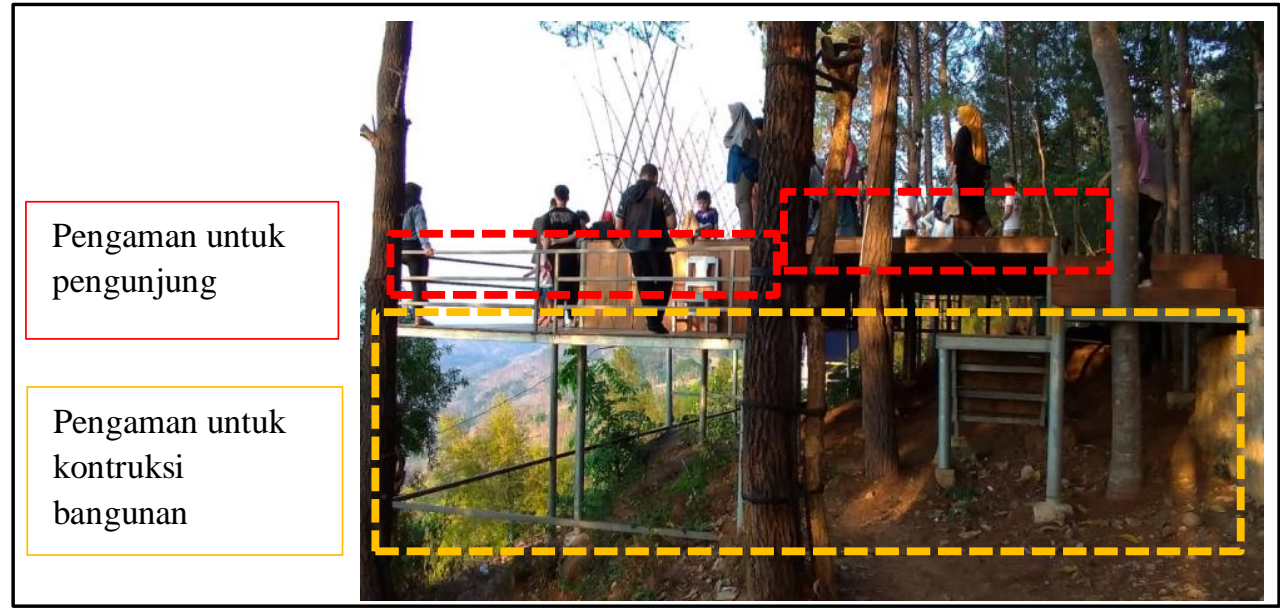

Gambar 4. Kondisi Pengaman Amphititer atau Panggung di Kawasan Puncak Becici (Sumber: Penulis)

Terlepas dari itu pembangunan panggung yang berada dikawasan Puncak Becici secara keamanan masih perlu ditinggatkan, baik dari sisi kontruksi maupun sisi pengaman disekitar panggung. Ha tersebut dapat dilihat pada Gambar 4.

7. Sarana Parkir Kendaraan

Sarana parkir kendaraan di kawasan Puncak Becici mampu di pakai untuk kendaraan roda dua maupun kendaraan roda empat, tempat perkir tersebut berada di kawasan luar dari objek wisata. Saat ini pengembangan kawasan parkir masih dilakukan dengan membuka dan memanfaatkan areal-areal disekitar kawasan. Pembuatan tempat kawasan parkir dilakukan dengan melakukan pengurukan atau pemerataan lahan yang ada dikawasan tersebut.

8. Talud Pengaman Tebing

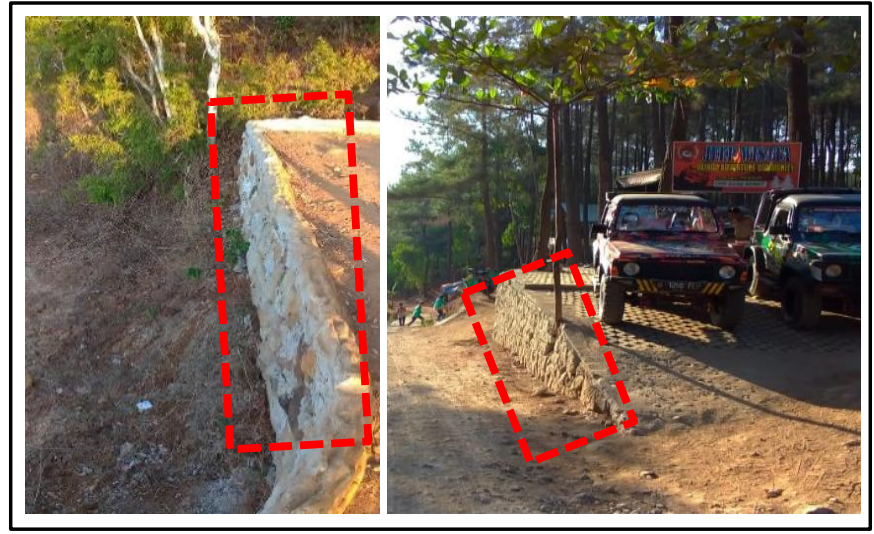

Gambar 5. Beberapa Bangunan Talud Pengaman di Kawasan Puncak Becici (Sumber: Penulis)

Pembangunan fasiltas-fasilitas lain yang berada di kawasan Puncak Becici dalam rangka untuk keamanan kawasan baik dari lonsor maupun yang lainnya sudah dilakukan, antar lain pembuatan pondasi batu dan pelindung lainnya. Pembangunan talud atau pondasi untuk pelindung lonsor maupun sebagai pembatas areal, seperti areal parkir dengan areal yang lain, sehingga kedepan konsep wisata yang aman dan nyaman. 


\subsection{Analisis Perubahan Ekosistem}

Perkembangan kawasan wisata dapat menjadi faktor yang mempengaruhi perubahan ekosistem. Perkembangan yang dapat mempengaruhi hal tersebut dapat dilihat dari beberapa indikator seperti kunjungan wisatawan yang selalu meningkat dalam kurun waktu 5 tahun, fasilitas pariwisata yang selalu meningkat, yang awalnya hanya 2 menjadi 21 kemuadian dapat menjadi 27, bertambahnya atraksi wisata dengan banyaknya kegiatan wisata yang dapat dilakukan, dan masyarakat bersedia untuk berpartisipasi sebagai penyedia fasilitas pariwisata (BUTLER, 1980). Dari indikator di atas, kawasan wisata Hutan Pinus Puncak Becici mengalami peningkatan kunjungan wisatawan sampai tahun 2019. Berikut analisis perubahan yang terjadi pada ekosistem kawasan wisata Hutan Pinus Puncak Becici.

\subsubsection{Perubahan Geofisik}

1. Air

Air mendapatkan pencemaran dari pembuangan limbah cair (detergen pencucian, MCK, dll) dan limbah padat (sisa makanan wisatawan). Limbah-limbah itu mencemari tanah dan sungai. Akibat dari pembuangan limbah, maka lingkungan terkontaminasi, kesehatan masyarakat terganggu, perubahan dan kerusakan vegetasi, dan air yang terkontaminasi zat pencemar sehingga dapat membahayakan. Guna mengurangi pencemaran air, maka pembangunan pengolahan limbah terpadu harus dibangun dengan standar yang baik tanpa kebocoran dan tidak mencemari lingkungan.

Dampak dari pembangunan sektor wisata terhadap sumber daya air bersih akan terjadi penurunan kualitas (karena pencemaran) dan penurunan kuantitasnya, (yakni karena berkurang debit aliran air) menjadi ancaman nyata bagi manusia.

Tidak semua kawasan objek wisata mempunyai sumber air yang bagus dan melimpah, begitu juga di kawasan wisata puncak becici yang mengandalkan persediaan air pada musim penghujan. Apabila musim kemarau suplai air dari bawah dikawasan permukiman warga, namun apabila kemarau panjang kebutuhan air diperoleh dari membeli air dengan menggunakan tangki.

2. Udara

Pencemaran udara karena kesalahan penyelenggaraan wisata seringkali mengancam kesehatah manusia. Pencemaran udara sebagai dampak pengembangan industri pariwisata antara lain bersumber dari pembakaran gas dan terlepasnya bahan-bahan beracun diudara. Ada banyak bukti konsumsi sumber daya alam menjadi meningkat dan berlebih, banyaknya kendaraan bermotor yang masuk dalam kawasan wisata puncak becici sebagai bagian dari meningkatnya kunjungan wisata, serta daya tarik wisata dengan memanfaatkan kendaraan sebagai salah satu bagian atraksi dikawasan tersebut. Hasil buangan emisinya dilepas di udara yang menyebabkan udara tercemar. Selain itu, udara tercemar akibat emisi kendaraan, bunyi deru mesin kendaraan menyebabkan polusi juga yaitu kebisingan. Akibat polusi udara dan polusi suara, maka nilai wisata berkurang, pengalaman menjadi tidak menyenangkan dan memberikan dampak negatif bagi vegetasi, flora dan fauna. Inovasi kendaraan ramah lingkungan dan angkutan atau akomodasi wisata berpenumpang massal (seperti transportasi wisata dengan kapasitas lebih banyak penumpang sekali jalan) dilakukan guna menekan polusi udara dan suara. Anjuran untuk mengurangi kendaraan bermotor juga dilakukan dan kampanye berwisata sepeda ditingkatkan.

\section{Tanah}

Kawasan wisata pegunungan memberikan aktivitas dipegunungan berpotensi merusak kawasan tersebut. Pembukaan lahan dengan melakukan penebangan yang dijadikan untuk peningkatan pembangunan infrastruktur, pembangunan jalan setapak (corblok), dan pembangunan fasilitas lainnya merupakan beberapa contoh pembangunan yang berpotensi merusak tanah kawasan pegunungan. Akibatnya semakin luas bukaan tutupan lahan, terjadi tanah longsor, erosi tanah, menipisnya vegetasi pegunungan (yang bisa menjadi paru-paru masyarakat), potensi polusi visual dan banjir dibawahnya yang berlebihan karena tanah tidak mampu menyerap air hujan. Reboisasi (penanaman kembali 
pepohonan di kawasan wisata) dan peremajaan tanaman dilakukan sebagai upaya pencegahan kerusakan tanah dipegunungan.

4. Vegetasi

Pembalakan liar, pembabatan pepohonan, bahaya kebakaran hutan (akibat puntung rokok yang dibuang sembarangan), koleksi bunga, tumbuhan dan jamur untuk kebutuhan wisatawan merupakan beberapa kegiatan yang merusak vegetasi. Akibatnya, terjadi degradasi hutan (berpotensi erosi lahan), perubahan struktur tanaman (misalnya pohon yang seharusnya berbuah setiap tiga bulan berubah menjadi setiap enam bulan, bahkan menjadi tidak berbuah), hilangnya spesies tanaman langka dan kerusakan habitat tumbuhan. Ekosistem vegetasi menjadi terganggu dan tidak seimbang.

\section{Kehidupan Satwa}

Kehidupan satwa menjadi daya tarik wisata yang luar biasa. Wisatawan terpesona dengan pola hidup hewan. Namun, kegiatan wisata mengganggu kehidupan satwa-satwa tersebut. Komposisi fauna berubah akibat pemburuan hewan sebagai cenderamata, pelecehan satwa liar untuk fotografi, eksploitasi hewan untuk pertunjukan (Urbanus \& Febianti, 2017), gangguan reproduksi hewan (berkembang biak), perubahan insting hewan (contoh, komodo yang dahulunya hewan ganas menjadi hewan jinak yang dilindungi), migrasi hewan (ke tempat yang lebih baik). Jumlah hewan liar pun akhirnya berkurang. Akibatnya, ketika wisatawan mengunjungi daerah wisata, tidak akan lagi mudah menemukan satwasatwa tersebut.

\subsubsection{Perubahan Luasan Tutupan Lahan}

Perubahan tutupan lahan dari suatu wilayah dapat dilakukan untuk mendeteksi perubahan lingkungan pada suatu wilayah. Data perubahan tutupan lahan secara periodik dapat mengidentifikasi seberapa luas berkurangnya suatu lahan atau bertambahnya suatu laha. Data tutupan lahan secara periodik bisa dilihat dalam data satellite. Data satelite dapat mengklasifikasikan jenis tutupan lahan yang ada pada suatu wilayah. Perubahan jenis tutupan lahan dapat dilihat dari luasan yang dibandingkan dari data tersebut secara periodik.

Dalam menganalisis perubahan tutupan hutan di kawasan hutan lindung dilakukan pengunduhan citra secara berkala mulai tahun 2015 sampai dengan tahun 2019. Dalam kurun waktu sampai dengan tahun 2016 dapat dilihat bahwa kawasan hutan lindung masih belum ada bangunan. Semua areal kawasan hutan lindung tertutup oleh vegetasi hutan. Dengan ini fungsi kawasan hutan lindung sesuai dengan Penjelasan Pasal 5 ayat 2 UU no 26 tahun 2007 a, yang disebutkan bahwa kawasan yang memberikan pelindungan kawasan bawahannya, antara lain, kawasan hutan lindung, dan juga kawasan resapan air (Republik Indonesia, 2007). Luasan bukaan tutupan lahan dari tahun 2015 sampai dengan tahun 2019 dapat dilihat pada Tabel 1.

Tabel 1. Luas Bukaan Tutupan Lahan Hutan Pinus Puncak Becici

\begin{tabular}{ccc}
\hline No & Tahun & Luas Bukaan Tutupan Lahan (hektar) \\
\hline $\mathbf{1}$ & 2015 & 0,2 \\
\hline $\mathbf{2}$ & 2016 & 0,24 \\
\hline $\mathbf{3}$ & 2017 & 1,0 \\
\hline $\mathbf{4}$ & 2018 & 1,7 \\
\hline $\mathbf{5}$ & 2019 & 2,19 \\
\hline
\end{tabular}

Berdasarkan Tabel 1, dapat dilihat bahwa luasan bukaan tutupan lahan selama 5 tahun terakhir terus bertambah besar. Lebih dari 2 hektar lahan sudah dibuka di kawasan Puncak Becici selama 5 tahun. Dari Tabel 1 dapat dilihat bahwa pada tahun 2015 dan 2016 tidak terlihat perubahan signifikan dalam pertambahan luas tutupan lahan. Namun, terjadi peningkatan cukup tinggi semenjak tahun 2017. Pada 
tahun tersebut, wisatawan yang datang semakin meningkat setelah kedatangan Mantan Presiden Amerika Serikat, Barrack Obama.

Pertambahan areal terbuka menjadi lebih luas dapat dilihat dalam citra google earth tahun 2018 dan bertambah lagi sampai tahun 2019. Perubahan ini kalau tidak dikendalikan dapat menyebabkan mengubah fungsi kawasan hutan lindung. Perubahan areal tutupan menjadi terbuka di tengah-tengah yang di kelilingi dengan kawasan tertutup oleh pohon dapat menyebabkan perbedaan tekanan udara yang besar, terutama pada musim kemarau panjang. Zona pada permukaan tanah yeng terbuka dapat meningkat suhu udara dan pada saat yang sama terjadi menurunnya tekanan udara. Pada saat yang sama, areal sekelilingya dengan tutupan vegetasi hutan yang lebat terjadi suhu udara relatif lebih rendah dan tekanan yang relatif lebih tinggi, dibanding dengan areal terbuka di tengahnya. Dengan kondisi seperti ini pada saat musim kemarau akan menyebabkan adanya aliran udara dengan kecepatan tingi dari tekanan udara tinggi ke tekanan udara rendah, yang dapat menjadi puting beliung. Hal ini sudah terjadi kerusakan yang berat di wilayah lain pada areal terbuka tersebut dengan menyebaban bencana alam, yang ditimbulkan oleh perubahan tutupan lahan karena aktivitas manusia. Hal ini perlu dicegah dengan melakukan antisipasi untuk tidak terjadi di areal kawasan hutan lindung di Becici.

Akibat pembukaan tutupan lahan pada musim hujan juga dapat terjadinya erosi tanah yang sangat besar di arela tutupan lahan. Aliran runoff pada saat hujan deras dapat merusak lingkungan kawasan hutan lindung Becici. Pembangunan sarana prasarana berupa bangunan, jalan, dan aktivitas pengunjung dapat mengurangi fungsi tanah dalam enginfiltrasi air hujan. Peningkatan runoff yang besar dapat menyebabkan tergerusnya tanah di kawasan hutan pinus. Curah hujan yang tinggi menyebabkan suatu kawasan wisata dengan kemiriingan lereng yang terjal memiliki kewarawanan yang tinggi seperti yang sudah diteliti di kawasan wisata Desa Mangunan yang terletak tidak jauh dari kawasan Wisata Puncak Becici (Rumaisha \& Haryono, 2019).

Kawasan hutan dengan dominan vegetasi tanaman tahunan mempuyai karakteristik menutupi permukaan tanah dengan jarak tajuk pohon sampai tanah cukup tinggi. Sehingga seresah hasil rontokan ranting dan daun di permukaan tanah sangat diperlukan untuk menjaga infilrasi air masuk kedalam tanah. Dengan bertambahnya tutupan sarana dan prasarana serta bagunan prnunjang rekreasi dapat menyebabkan penurunan infiltrasi, dan sebaliknya peningkatan runoff yang menyebabkan terjadinya erosi yang besar. Disamping itu aliran air ini dapat menyebabkan terjadinya banjir atau genangan pada areal di bawahnya. Di samping itu yang lebih parah lagi adalah potensi terjadinya longsor, mengingat areal kawasan hutan lindung ini juga mempunyai kemiringan lereng yang curam.

\section{KESIMPULAN}

a. Perkembangan kawasan wisata Hutan Pinus Puncak Becici, Dlingo menyebabkan perubahan fisik pada kawasan tersebut.

b. Perubahan-perubahan yang terjadi dapat dilihat dari perubahan luas bukaan tutupan lahan yang meningkat dan pembangunan fasilitas kawasan wisata yang meningkat. Total luas bukaan tutupan lahan pada tahun 2019 adalah sekitar 2,19 hektar.

\section{UCAPAN TERIMA KASIH}

Terimakasih kepada Dinas Lingkungan Hidup Kabupaten Bantul atas kesempatan yang diberikan kepada kami untuk mengkaji penelitian ini. Terimakasih juga ditujuakan kepada Universitas Pembangunan Nasional Veteran Yogyakarta yang sudah mendukung peneliti dalam melakukan kajian.

\section{DAFTAR PUSTAKA}

Bantul, B. P. S. K. (2019). Kabupaten Bantul Dalam Angka 2019.

BUTLER, R. W. (1980). The Concept Of A Tourist Area Cycle Of Evolution: Implications For 
Management Of Resources. The Canadian Geographer / Le Géographe Canadien, 24(1), 5-12. https://doi.org/10.1111/j.1541-0064.1980.tb00970.x

Butler, R. W., \& Pearce, D. G. (2003). Tourism Development. Taylor \& Francis.

Dörnyei, Z. (2007). Research Methods in Applied Linguistics: Quantitative, Qualitative, and Mixed Methodologies. OUP Oxford. Retrieved from https://books.google.co.id/books?id=R4dNAQAAMAAJ

Ismayanti. (2010). Pengantar pariwisata. Gramedia Widiasarana Indonesia (Grasindo).

Jogja, P. (2019). 21 Tempat Wisata dan Tiket masuk Kawasan Dlingo. Retrieved from https://www.pesonajogjatour.net/2019/07/tiket-masuk-tempat-wisata-dlingo.html

Republik Indonesia, P. Keputusan Presiden Republik Indonesia Nomer 32 Tahun 1990 Tentang Pengelolaan Kawasan Lindung (1990). Indonesia.

Republik Indonesia, P. Undang-Undang Republik Indonesia Nomer 26 Tahun 2007 Tentang Penataan Ruang (2007). Indonesia.

Rumaisha, \& Haryono, E. (2019). Kajian Kerawanan Tanah Longsor pada Objek Pariwisata Swafoto Di Desa Wisata Mangunan, Dlingo, Bantul. JURNAL BUMI INDONESIA, 8(2). Retrieved from http://lib.geo.ugm.ac.id/ojs/index.php/jbi/article/view/1070

Sinery, A. S., \& Mahmud. (2014). Fungsi Kawasan Dan Strategi Pengelolaan Hutan Lindung Wosi Rendani Kabupaten Manokwari. Agrifor, XIII(2).

Urbanus, N., \& Febianti. (2017). Analisis dampak perkembangan pariwisata terhadap perilaku konsumtif masyarakat wilayah bali selatan. Jurnal Kepariwisataan Dan Hospitalitas, 1(No.2), $118-133$.

Zuraya, N. (2017). Obama dan Keluarga Berwisata ke Puncak Becici Dlingo. Republika. Retrieved from https://republika.co.id/berita/gaya-hidup/pesona-indonesia/17/07/01/osed16383-obamadan-keluarga-berwisata-ke-puncak-becici-dlingo 